\title{
Overview of the bird diversity in oak (Quercus spp.) forest habitats in Isparta province, southwestern Turkish Anatolia
}

\author{
Adam Bergner ${ }^{\text {a,* }}$, Ogün Çağlayan Türkay ${ }^{a}$, Hasan Eryiğit ${ }^{b}$, Mustafa Avcı ${ }^{c}$
}

\begin{abstract}
Natural and semi-natural oak (Quercus spp.) forests in Turkey are rich ecosystems of high conservation value that are increasingly threatened by logging and transformation into coniferous plantations. They harbor a diverse fauna and flora, but the current knowledge of their associated biodiversity is limited for many groups of organisms. In this paper, we present our preliminary results from inventories of the birds inhabiting various oak forests located in Isparta province in southwestern Turkish Anatolia. The bird species diversity was assessed both quantitatively and a qualitatively using random observation walks and fixed-radii point counts in 17 oak forests ranging in mean age from 30 years up to 300 years. A total of 52 bird species belonging to 43 genera and 24 families were identified. The three most abundant species were Eastern Bonelli's Warbler (Phylloscopus orientalis), Common Chaffinch (Fringilla coelebs) and Common Blackbird (Turdus merula). Birds of national or international conservation concern are highlighted. Furthermore, we present an updated taxonomical species checklist.

Keywords: Quercus, Birds, Succession, Indicator, Habitat
\end{abstract}

\section{Güneybatı Türkiye, Isparta ili meşe (Quercus spp.) ormanı habitatlarındaki kuş çeşitliliği üzerine genel bir bakış}

\begin{abstract}
Özet: Türkiye'nin güneybatısındaki doğal ve yarı doğal meşelikler yüksek koruma statüsüne sahip zengin ekosistemler olmakla birlikte, artan üretim ve konifer plantasyonlarına dönüştürülme tehditleri ile karşı karşıyadırlar. Bu özel ekosistemlerin zengin fauna ve flora çeşitliğini barındırdığı bilinmektedir, ancak pek çok tür için biyoçeşitlilikle ilgili mevcut bilgilerimiz oldukça sınırlıdır. Bu makalede, Türkiye'nin güneybatısında yer alan Isparta ilinde farklı meşe türlerinden oluşan orman alanlarında bulunan kuş türlerine ait elde edilen ilk envanter sonuçları verilmektedir. Çalışmada kuş türlerine ait çeşitlilik, hem nicelik hem nitelik bakımından değerlendirilmiş olup, içindeki fert yaşlarının 30-300 arasında değişkenlik gösterdiği, 17 meşelik alanda, rasgele belirlenen hatlar üzerinde ve sabit çaplı alanlarda gözlem ve tespitler yapılmıştır. Çalışma sonucunda, 24 familya, 43 cinse ait 52 kuş türü belirlenmiştir. En fazla rastlanan üç tür; Boz çıvgın (Phylloscopus orientalis), İspinoz (Fringilla coelebs) ve Karatavuk (Turdus merula) olarak tespit edilmiştir. Makalede kuşların ulusal ve uluslararası koruma statülerine de değinilmiş olup, güncel taksonomik tür listesi de verilmiştir.
\end{abstract}

Anahtar kelimeler: Quercus, Kuşlar, Süksesyon, İndikatör, Habitat

\section{Introduction}

Turkey is home to more species of oak (Quercus sp.) than any other country in Europe and the Middle East, at least 17 species of which three are considered nationally endemic (Kavgaci et al., 2010; Uğurlu et al., 2012). The different oak species are distributed all over the country, with the highest diversity in Marmara region (Uslu et al., 2011), covering nearly six million hectares of the land area or $26 \%$ of the Turkish forests (OGM, 2015). Previously commonly utilized for pollarding, coppicing and grazing, oak forests in Turkey have an old tradition as important sources of livelihood for rural communities (Kaniewski et al., 2007). Extensive urbanization during the last century has put large pressures on the natural forests in demands for natural resources (Kaya and Raynal, 2001; Atmiş et al., 2007). Nowadays, a common measure is to convert natural or semi-natural broadleaved forests into monocultures of coniferous plantations, mainly Lebanon Cedar (Cedrus libani) and Turkish Pine (Pinus brutia) (Çolak and Rotherham, 2006; Sama et al., 2011). To advocate for conservation of valuable forest habitats, suitable indicator organisms need to be identified, studied and evaluated. Birds are generally regarded as suitable wildlife indicators (Furness et al., 1993) and are commonly and globally used in environmental monitoring. This is due to several factors: 1) birds are comparatively well-known and easy to detect and identify in the field (Gregory et al., 2005), 2) most birds exhibit fast responses to environmental change (Gregory and van Strien, 2010) and 3) many birds are ecologically linked to other organisms due to their behavior, utilization and exploitation of resources and habitats, thus may provide various ecosystems with keystone functions (Bednarz et al., 2000; Pereira et al., 2014; Bereczki et al., 2014). Birds work

\footnotetext{
$\bowtie$ a IFM Biology, Conservation Ecology Group, Linköping University, Linköping, Sweden

b Isparta Provincial National Parks Directorate, Isparta, Turkey

c Faculty of Forestry, Isparta University of Applied Sciences, Isparta, Turkey

@ * Corresponding author (İletişim yazarı): adam.bergner@ gmail.com

$\checkmark \quad$ Received (Geliş tarihi): 28.05.2018, Accepted (Kabul tarihi): 17.12.2018
}

Citation (Atıf): Bergner, A., Türkay, O.C. Eryiğit, H., Avc1, M., 2018. Overview of the bird diversity in oak (Quercus spp.) forest habitats in Isparta province, southwestern Turkish Anatolia. Turkish Journal of Forestry, 19(4): 347-354. DOI: $10.18182 /$ tjf.427726 
well as overall barometers of environmental health as long as summarized data from a wide range of species is included (Bibby, 1999). Because of that thorough knowledge of the species composition is crucial to correctly interpret relationships between groups of species and important habitat features (Müller and Hothorn, 2004). In turn, this may be a prerequisite for the development of successful and sustainable management and conservation of various habitats and the structures within these habitats. Despite being a particularly rich country in terms of breeding bird species, Turkey has been subjected to few systematic bird surveys (Kirwan et al., 2008) including inventories of birds in geographical areas or specific types of habitats. Turkish oak forests have been suggested as important habitats for several bird species, among them highly specialized groups of species that feed upon invertebrates or nest in trunk cavities (Bergner et al., 2015; Bergner et al., 2016). Lack of sufficient knowledge about the bird species composition in oak forests in southwestern Turkey promoted for the overview presented here. The study aimed at detecting the full spectrum of species that, at any stage of forest succession, utilize oak habitats during the breeding season. Additionally, to put our results into a larger perspective, we evaluate the conservation status for a couple of species that are red-listed or included in the European Union's Bird Directive (Birdlife International, 2017) and suggest potential indicator birds for future environmental evaluations seeking to identify oak habitats of high conservation value.

\section{Materials and methods}

\subsection{Study area}

The study was carried out in Isparta province, located near the northern edge of the Taurus Mountains in southwestern Turkey (Figure 1). The region has a continental climate with hot, dry summers and cold, rainy winters (MGM, 2017). The forested areas are primarily made up of planted coniferous forests (mainly Turkish Pine, Lebanon Cedar and Black Pine). Most valleys and plains are cultivated, grown with cereals, roses and fruits such as apples and cherries. Some valleys and slopes contain scattered patches of natural or near-natural oak forests, mainly former coppices currently grazed by domestic animals. Habitats made up of old oaks remain as a rare element where traditional sheep and goat husbandry is still being practiced.

\subsection{Selection of study sites}

We selected suitable oak forest habitats using geographical information system (GIS) provided by the Regional Directorate of Forestry in Isparta province. We made a random selection of 17 forests (Figure 1) ranging in mean stand age from 30 years up to 300 years, determined by means of dendrology using a Swedish $5 \mathrm{~mm}$ increment borer (Haglöf Sweden AB). These forests contained one or a few of any of the oak species' Quercus cerris, $Q$. ithaburensis, $Q$. vulcanica, $Q$. infectoria, $Q$. trojana and $Q$. coccifera. The forests were located at altitudes ranging from 980 to $1520 \mathrm{~m}$. a.s.l.

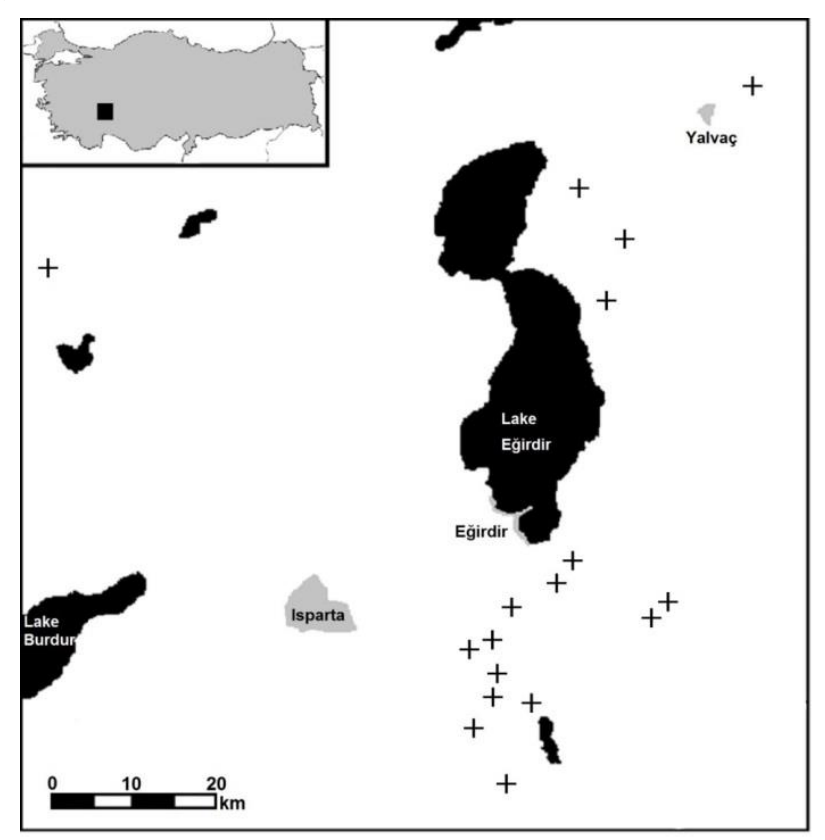

Figure 1. Map of the Isparta province and study sites, represented by black crosses

\subsection{Bird surveys}

\subsubsection{Point counts}

The point counts aimed at yielding a standardized quantitative and qualitative measure of the bird species diversity in the oak forest habitats. Counts were carried out using a slightly altered fixed-radius point taxation method previously described by Verner (1985) and Hutto et al. (1986). In our study, each forest was given four points (at least $120 \mathrm{~m}$ apart to avoid double counting), randomly put out in the interior parts of each forest, at least $80 \mathrm{~m}$ from edges. The points were later located in field using a Garmin GPS. Red paint was sprayed on tree trunks to mark the spots for point observations. All territorial birds (displaying or agitated birds) that were present within a fifty meter radius were carefully registered during periods of 10 minutes. A measuring tape was used as a reference to determine the size of the radius. Each point received two visits, one carried out before lunch (9-12 AM) and one in the afternoon (15-18 PM), using a three-week interval within the period May 6 to June 29, 2013. The observer wore all green clothing to blend in with the surrounding environment and minimize avoidance of birds. Birds were detected and identified either by sounds or direct observation using a pair of $8 \times 32$ Swarovski binoculars. Svensson et al., (2009) and Roché et al., (2001) were used as references for identification of birds. All bird surveys were carried out by one person (AB) to limit potential effects of observer bias. Every bird in display or exhibiting an agitated behavior was assumed equal to one established breeding territory. The final amount of territories for each species is based on the maximum number of individuals noted during any of the two visits in each forest. For a species to be confirmed as breeding there had to be either observations of adults visiting nests or seen feeding chicks (in nest or as newly fledged). If neither of these criteria were met but the species were observed either displaying, exhibiting an agitated behavior or occurring in coupled pairs it was considered as likely breeding. A few 
species are known to breed in Turkey but were just observed occasionally, without any indications of breeding, and their breeding status therefore is not known. Bird species that regularly appear in the oak forests during migration and are known not to breed in Turkey, such as Willow Warbler (Phylloscopus trochilus), Blackcap (Sylvia atricapilla) and Collared Flycatcher (Ficedula albicollis), were excluded from the study.

\subsubsection{Observation walks}

The observation walks were carried out in the same areas as the standardized point counts and primarily aimed at yielding an improved qualitative measure of the bird species diversity by somewhat complement the dataset from the point counts. No counting of bird individuals was performed during any of the observation walks. Neither did we record the lengths of any observation walks, however most were conducted while walking between coordinates for the standardized point counts. The observation walks covered larger areas than the point counts, why some of the less abundant species could be recorded.

\section{Results}

\subsection{Point counts}

Using the method of standardized point counts we registered a total of 556 territories of 38 species belonging to 32 genera and 19 families (Table 1). There were strong indications of breeding (breeding confirmed or breeding likely) for 36 species. The most abundant species were found to be the Eastern Bonelli's Warbler, a small insectivorous passerine, making up $14.6 \%$ of all birds registered (Figure 2) with an estimated territory density of 2.7 pairs per hectare. The second and third most abundant species were Common Chaffinch (14.2\%) and Common Blackbird (8.3\%). The Krüper's Nuthatch constitutes the only species of former international conservation concern, previously classified as "Near Threatened" (IUCN, 2015), but now placed in the category of "Least Concern" whilst having a declining global population (IUCN, 2018). In addition to Krüper's Nuthatch, another six species (Syrian Woodpecker, Middle Spotted Woodpecker, Rüppell's Warbler, Olive-tree Warbler, Ortolan Bunting and Cretzschmar's Bunting) are placed in the Annex I list of birds with a high conservation priority according the European Union's Bird Directive (Birdlife International, 2017).

\subsection{Observation walks}

During the observation walks an additional set of 13 species belonging to 12 genera and nine families were registered (Table 2). Out of these, nine species showed strong indications of breeding. The most noteworthy finding was an incubating European Honey Buzzard in a dense coppice forest near the village of Çayköy, southeast of Eğirdir. The European Honey Buzzard is an uncommon breeding species in Turkey, considered nationally red listed (Kılıç and Eken, 2004) without any previously confirmed nesting records in the country (Kirwan et al., 2008). Four species (European Honey Buzzard, European Nightjar, Wood Lark and Lesser Grey Shrike) are placed in the Annex I list of birds with a high conservation priority according to the European Union's Bird Directive (Birdlife International, 2017).

Table 1. Birds identified in the fixed-radii point taxation inventories, presented according to taxonomy. The assessed breeding status in oak forests in Isparta Province is also given.

\begin{tabular}{|c|c|c|c|c|}
\hline Family name & Scientific family name & Species name & Scientific name & Status \\
\hline \multirow[t]{5}{*}{ True warblers } & Sylviidae & & & \\
\hline & & Eastern Bonelli's Warbler & Phylloscopus orientalis & Breeding \\
\hline & & Eastern Orphean Warbler & Sylvia crassirostris & Breeding \\
\hline & & Rüppell's Warbler & Sylvia ruppelli & Breeding \\
\hline & & Lesser Whitethroat & Sylvia curruca & Breeding \\
\hline \multirow[t]{3}{*}{ Acrocephaline warblers } & Acrocephalidae & & & \\
\hline & & Olive-tree Warbler & Hippolais olivetorum & Breeding \\
\hline & & Eastern Olivaceous Warbler & Iduna pallida & Breeding likely \\
\hline \multirow[t]{2}{*}{ Shrikes } & Lanidae & & & \\
\hline & & Masked Shrike & Lanius nubicus & Breeding \\
\hline \multirow[t]{6}{*}{ Woodpeckers } & Picidae & & & \\
\hline & & European Green Woodpecker & Picus viridis & Breeding \\
\hline & & Greater Spotted Woodpecker & Dendrocopus major & Breeding \\
\hline & & Syrian Woodpecker & Dendrocopus syriacus & Breeding \\
\hline & & Middle Spotted Woodpecker & Leiopicus medius & Breeding \\
\hline & & Lesser Spotted Woodpecker & Dryobates minor & Breeding likely \\
\hline \multirow[t]{2}{*}{ Long-tailed Tits } & Aegithalidae & & & \\
\hline & & Long-tailed Tit & Aegithalos caudatus & Breeding \\
\hline \multirow[t]{4}{*}{ Tits } & Paridae & & & \\
\hline & & Coal Tit & Periparus ater & Breeding likely \\
\hline & & Blue Tit & Cyanistes caeruleus & Breeding \\
\hline & & Great Tit & Parus major & Breeding \\
\hline \multirow[t]{3}{*}{ Nuthatches } & Sittidae & & & \\
\hline & & Eurasian Nuthatch & Sitta europaea & Breeding \\
\hline & & Krüper's Nuthatch & Sitta krueperi & Not known \\
\hline \multirow[t]{2}{*}{ Old world orioles } & Oriolidae & & & \\
\hline & & Golden Oriole & Oriolus oriolus & Breeding \\
\hline
\end{tabular}


Table 1. continued

\begin{tabular}{|c|c|c|c|c|}
\hline Family name & Scientific family name & Species name & Scientific name & Status \\
\hline \multirow[t]{5}{*}{ Old world flycatchers } & Muscicapidae & & & \\
\hline & & Common Nightingale & Luscinia megarhynchos & Breeding \\
\hline & & Common Redstart & Phoenicurus phoenicurus & Breeding likely \\
\hline & & Spotted Flycatcher & Muscicapa striata & Breeding likely \\
\hline & & European Robin & Erithacus rubecula & Breeding \\
\hline \multirow[t]{2}{*}{ Wrens } & Troglodytidae & & & \\
\hline & & Eurasian Wren & Troglodytes troglodytes & Breeding likely \\
\hline \multirow[t]{3}{*}{ Thrushes } & Turdidae & & & \\
\hline & & Common Blackbird & Turdus merula & Breeding \\
\hline & & Mistle Thrush & Turdus viscivorus & Breeding likely \\
\hline \multirow[t]{2}{*}{ Pigeons } & Columbidae & & & \\
\hline & & European Turtle Dove & Streptopelia turtur & Breeding likely \\
\hline \multirow[t]{2}{*}{ Hoopoes } & Upupidae & & & \\
\hline & & Hoopoe & Upupa epops & Breeding \\
\hline \multirow[t]{2}{*}{ Treecreepers } & Certhiidae & & & \\
\hline & & Short-toed Treekreeper & Certhia brachydactyla & Breeding likely \\
\hline \multirow{2}{*}{ Corvids } & Corvidae & & & \\
\hline & & Eurasian Jay & Garullus glandarius & Breeding \\
\hline \multirow[t]{2}{*}{ Starlings } & Sturnidae & & & \\
\hline & & Common Starling & Sturnus vulgaris & Breeding \\
\hline \multirow[t]{5}{*}{ True finches } & Fringillidae & & & \\
\hline & & Eurasian Chaffinch & Fringilla coelebs & Breeding \\
\hline & & European Goldfinch & Carduelis carduelis & Breeding \\
\hline & & European Greenfinch & Chloris chloris & Breeding \\
\hline & & Serin & Serinus serinus & Breeding likely \\
\hline \multirow[t]{2}{*}{ Sparrows } & Passeridae & & & \\
\hline & & Eurasian Tree Sparrow & Passer montanus & Not known \\
\hline \multirow[t]{4}{*}{ Buntings } & Emberizidae & & & \\
\hline & & Ortolan Bunting & Emberiza hortulana & Breeding likely \\
\hline & & Cretzschmar's Bunting & Emberiza caesia & Breeding likely \\
\hline & & Cirl Bunting & Emberiza cirlus & Breeding likely \\
\hline
\end{tabular}

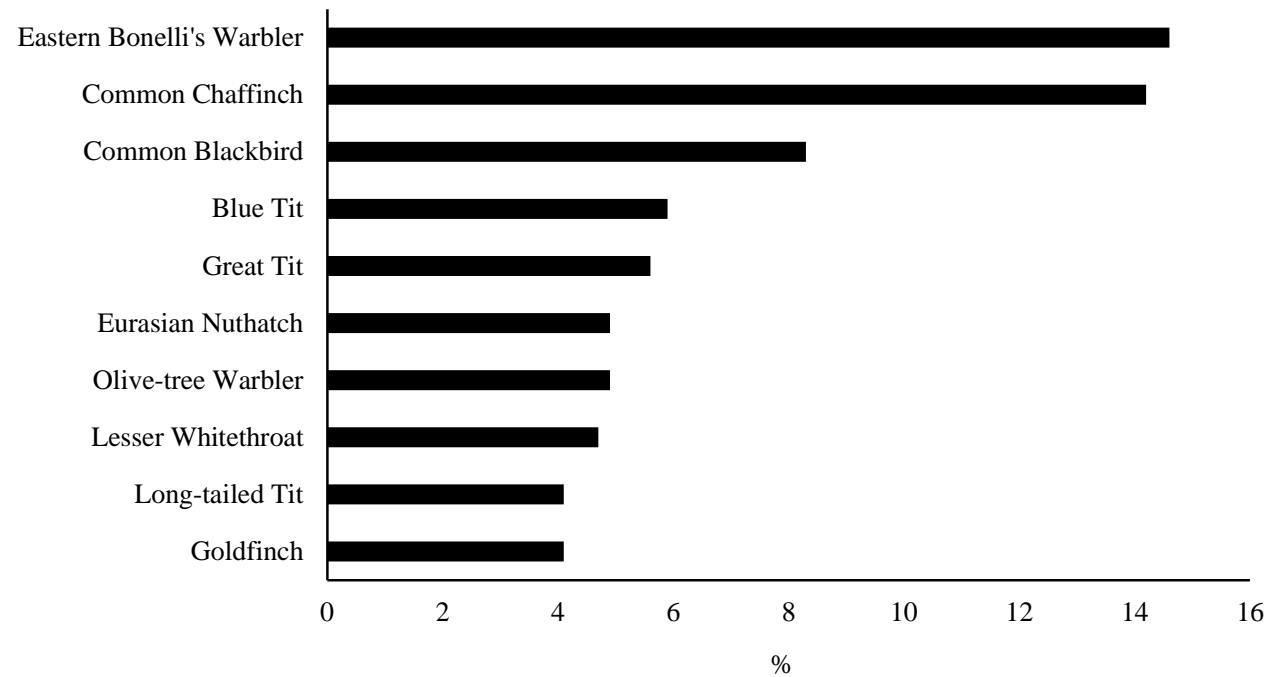

Figure 2. The ten most abundant bird species inhabiting oak forest habitats in Isparta province, expressed as percentage of the total number of bird territories $(n=556)$. 
Table 2. Birds identified in the observation walk inventories only, presented according to taxonomy. The assessed breeding status in oak forests in Isparta Province is also given.

\begin{tabular}{|c|c|c|c|c|}
\hline Family name & Scientific family name & Species name & Scientific name & Status \\
\hline \multirow[t]{3}{*}{ "Hawklike raptors" } & Accipitridae & & & \\
\hline & & Eurasian Sparrowhawk & Accipiter nisus & Not known \\
\hline & & European Honey Buzzard & Pernis apivorus & Breeding \\
\hline \multirow[t]{3}{*}{ True owls } & Strigidae & & & \\
\hline & & European Scops Owl & Otus scops & Breeding likely \\
\hline & & Little Owl & Athene noctua & Breeding likely \\
\hline \multirow[t]{2}{*}{ Nightjars } & Caprimulgidae & & & \\
\hline & & European Nightjar & Caprimulgus europaeus & Not known \\
\hline \multirow[t]{2}{*}{ Larks } & Alaudidae & & & \\
\hline & & Wood Lark & Lullula arborea & Breeding \\
\hline \multirow[t]{2}{*}{ Old world flycatchers } & Muscicapidae & & & \\
\hline & & Rufous-tailed Scrub-robin & Cercotrichas galactotes & Not known \\
\hline \multirow[t]{2}{*}{ Tits } & Paridae & & & \\
\hline & & Sombre Tit & Poecile lugubris & Breeding \\
\hline \multirow[t]{3}{*}{ Shrikes } & Lanidae & & & \\
\hline & & Lesser Grey Shrike & Lanius minor & Breeding likely \\
\hline & & Woodchat Shrike & Lanius senator & Breeding likely \\
\hline \multirow[t]{2}{*}{ Cuckoos } & Cuculidae & & & \\
\hline & & Common Cuckoo & Cuculus canorus & Breeding likely \\
\hline \multirow[t]{3}{*}{ True finches } & Fringillidae & & & \\
\hline & & Hawfinch & Coccothraustes coccothraustes & Not known \\
\hline & & Common Linnet & Linaria cannabina & Breeding likely \\
\hline
\end{tabular}

\section{Discussion}

\subsection{Importance of oak habitats for birds}

Our study indicates that oak forest habitats in the current region, at some point during the breeding season for birds, may function as suitable habitats for a wide variety of birds, among them several species of conservation concern in a European context. These findings highlight the importance of preserving and sustainably managing Turkish oak forests so that species particularly dependent upon these habitats may sustain in viable populations, not just in Turkey but in the eastern Mediterranean region as a whole. Since oaks can grow old and form habitats exhibiting a large variation in vegetation structure depending on climate, age and management, they attract many different bird species throughout hundreds of years of successional development (Moskát and Waliczky, 1992). Each successional stage is believed to harbor a specific assemblage of birds dependent upon the traits typical for that successional stage (Moskát, 1991). These assemblages include species with rather broad habitat preferences that may be present in forests of different structure (e.g. Parids (Paridae), Thrushes (Turdidae) and Eurasian Jay (Garrulus glandarius)), as well as species that are specialized on complex structures or scarce resources and confined to a narrow successional window (e.g. woodpeckers (Picidae)). The presence of some species is sometimes better explained by the structure, heterogeneity and connectivity of the landscape at larger spatial scales (e.g. Saab, 1999; Özkan et al., 2010) and may be a contributing factor for species less typical of oak forests to occur in such habitats if sufficient key habitat and resources are found in adjacent areas. This may be the case of the Krüper's Nuthatch, a species endemic to Turkish Anatolia, the Greek island of Lesvos and parts of the Caucasus region, which is generally considered strictly confined to coniferous forests (Albayrak and Erdoğan, 2018), but may occur, although rarely, in nearby deciduous forests (Albayrak and Erdogan, 2004).

\subsection{Changes in bird assemblages due to forest succession}

As different bird species have different needs in terms of e.g. food and access to nest sites the bird community clearly changes with the age and structure of oak forests. Young oak forests (here <50 years of age) are inhabited by several species typical of shrubby vegetation and semi-open habitats with scattered bushes and low as well as higher trees. Characteristic for these early stages of habitat succession are songbirds belonging to the genus Sylvia, such as Eastern Orphean Warbler and Lesser Whitethroat. They are considered to be among the first groups of birds originating in the Mediterranean maquis vegetation zone (Blondel and Farré, 1988). Other species found in these young shrub-like forests include a few species of Shrikes (Laniidae), as well as Olive-tree Warbler. As natural and near-natural forests grow older, they are becoming denser in structure as well as more homogeneous in terms of vegetation composition. The presence of birds of pure Mediterranean origin has been shown negatively associated with an increase in tree trunk density as forests age and develop (Telleria et al., 1992; Telleria and Santos, 1994; Rey-Benayas et al., 2010), resulting in the disappearance of several species. Instead, the avifauna develops in a direction giving rise to an assemblage similar to most deciduous forests in Europe and the Middle East, where a larger proportion of species place their nests in crotches of larger branches or small tree hollows (Cramp et al., 1993; Cramp and Perrins 1994a; 1994b). Medium-aged and mature, relatively dense, oak forests in Isparta province seem to be important habitats for Eastern Bonelli's Warbler and Rüppell's Warbler, two primarily insectivorous passerines. Furthermore, the forests also comprise a few species considered more generalists in terms of their wide food preferences, such as Common Blackbird, Great tit, Long-tailed Tit and Eurasian Jay. These species are not obbligato insectivorous, but also feed upon fruits, acorns and seeds or in some cases act as nestpredators of other birds (Cramp et al., 1993; Cramp and Perrins, 1994a; 1994b). 
Larger oak forests of considerable age are rare in Turkey (Jansson and Coskun, 2008) and primarily found in mountainous areas where traditional goat and sheep husbandry has been practiced for a long time (Kaniewski et al., 2007). Apart from grazing on the ground vegetation, the oaks have often been subjected to pollarding to extract wood used as food for domestic animals and timber for cooking and heating (Yaltirik, 1984; Ertuğ et al., 2004; Kiliç, 2015). This long-lasting anthropic management has created semiopen cultural habitats consisting of scattered old trees interspersed with few thorny shrubs. Owing to their semiopen structure and the mixture of shrubs and trees these habitats somewhat resemble oak forests in early stages of succession, why they also share common bird species assemblages, including Shrikes (Laniidae), a few songbirds of the genus Sylvia and Olive-Tree Warbler. Due to branch sheds and colonization of wood-living fungi, old oaks develop hollows and cavities after a few hundred years (Ranius et al., 2009), structures important as nesting places for mammals, birds and numerous invertebrates. Deadwood softened by fungi infestations provide suitable substrates for woodpeckers, where they create cavities for nesting (Touihri et al., 2015). Since woodpeckers generally create new cavities every year the abandoned cavities may later offer suitable nest sites for secondary cavity-nesting birds such as Great Tit, Blue Tit, Hoopoe and Common Starling (Robles et al., 2011). Woodpeckers are generally considered suitable indicator birds for valuable forest habitats (Drever et al., 2008), why their presence in Turkish oak forests should be carefully studied and monitored in order to find new potential oak areas of high conservation value. Developed oak forests combine the habitat attributes of several successional stages which increases the niche width and therefore are considered able to hold a particularly diverse bird fauna (Gil-Tena et al., 2007; Ding et al., 2008; Khanaposhtani et al., 2012). Thus, protection of areas with old oaks are crucial to sustain a broad spectrum of bird species and enable dispersal of these species to other suitable habitats in the landscape.

\subsection{Conclusions and management implications}

Turkish oak forests may be present in many different forms, offering a wide variety of resources and habitats for birds. The physical characteristics of oak forests are determined by a combination of the current successional stage as well as former and current habitat management, demonstrating the importance of not neglecting the habitat legacy when developing proper management schemes. For successful conservation of different oak forests and their associated bird fauna it is important to save as many representative components of habitat structure as possible in order to provide resources for both generalists and specialists (Julliard et al., 2006) and secure future availability and recruitment of new oak forests at different spatial scales (van Dorp and Opdam, 1987; Boulinier et al., 2001).

\section{Acknowledgements}

This study was part of a larger bird-surveying project of Anatolian forests and conducted in cooperation with the Regional Directorates of Forestry in Isparta, Eğirdir and Yalvaç. We are grateful for the logistic assistance provided by Osman Mücahit Doğan, Ayhan Başpinar, Mehmet Çakir, Halil Ibrahim Güzel, Kazım Kanlı, Cebrail Akaslan, Adnan Güller and Sibel Korkmaz. The project was financially supported by a scholarship grant provided by the Swedish International Development Cooperation Agency (SIDA).

\section{References}

Albayrak, T., Erdoğan, A., 2004. Habitat requirements for the nest preference and the distribution of Krüper's Nuthatch (Sitta krueperi) in Antalya. $1^{\text {st }}$ International Eurasian Ornithology Congress, 8-11.04.2004, Antalya, Turkey, pp.34-37.

Albayrak, T., Erdoğan, A., 2018. Distribution, density, and important hotspots of Krüper's Nuthatch Sitta krueperi in Turkey and Lesvos Island, Greece. Turkish Journal of Zoology, 42: 578-584.

Atmiş, E., Özden, S., Lise, W., 2007. Urbanization pressures on the natural forests in Turkey: an overview. Urban Forestry \& Urban Greening, 6: 83-92.

Bednarz, J.C., Ripper, D., Radley, P.M., 2000. Emerging concepts and research directions in the study of cavitynesting birds: keystone ecological processes. The Condor, 106: 1-4.

Bereczki, K., Ódor, P., Csóka, G., Mag, Z., Báldi, A., 2014. Effects of forest heterogeneity on the efficiency of caterpillar control service provided by birds in temperate oak forests. Forest Ecology and Management, 327: 96105.

Bergner, A., Avcı, M., Eryiğit, H., Jansson, N., Niklasson, M., Westerberg, L., Milberg, P., 2015. Influences of forest type and habitat structure on bird assemblages of oak (Quercus spp.) and pine (Pinus spp.) stands in southwestern Turkey. Forest Ecology and Management, 336: 137-147.

Bergner, A., Sunnergren, A., Yeşilbudak, B., Erdem, C., Jansson, N., 2016. Attributes of trees used by nesting and foraging woodpeckers (Aves: Picidae) in an area with old pollarded oaks (Quercus spp.) in the Taurus Mountains, Turkey. Zoology in the Middle East, 62: 288-298.

Bibby, C.J., 1999. Making the most of birds as environmental indicators. Ostrich, 70: 81-88.

BirdLife International, 2017. European birds of conservation concern: populations, trends and national responsibilities. Cambridge, UK: BirdLife International.

Blondel, J., Farré, H., 1988. The convergent trajectories of bird communities along ecological successions in European forests. Oecologia, 75: 83-93.

Boulinier, T., Nichols, J.D., Hines, J.E., Sauer, J.R., Flather, C.H., Pollock, K.H., 2001. Forest fragmentation and bird community dynamics: inference at regional scales. Ecology, 82: 1159-1169.

Çolak, A.H., Rotherham, I.D., 2006. A review of the forest vegetation of Turkey: its status past and present and its future conservation. Biology and Environment: Proceedings of the Royal Irish Academy, 106B: 343354.

Cramp, S., Perrins, C.M., Brooks, D.J., 1993. Handbook of the Birds of Europe, the Middle East and North Africa: The Birds of the Western Palearctic, Vol. 7. Oxford University Press, New York. 
Cramp, S., Perrins, C.M., Brooks, D.J., 1994a. Handbook of the Birds of Europe, the Middle East and North Africa. The Birds of the Western Palearctic, Vol. 8. Oxford University Press, New York.

Cramp, S., Perrins, C.M. , 1994b. Handbook of the Birds of Europe, the Middle East and North Africa: The Birds of the Western Palearctic, Vol. 9. Oxford University Press, New York.

Ding, T-S., Liao, H-C., Yuan, H-W., 2008. Breeding bird community in different successional vegetation in the montane coniferous forests zone of Taiwan. Forest Ecology and Management, 255: 2038-2048.

Drever, M.C., Aitken, K.E.H., Norris, A.R., Martin, K., 2008. Woodpeckers as reliable indicators of bird richness, forest health and harvest. Biological Conservation, 141: 624-634.

Ertuğ, F., Tümen, G., Çelik, A., Dirmenci, T., 2004. Buldan (Denizli) etnobotanik alan araştırması 2003. TÜBA Kültür Envanteri Dergisi, 2: 187-218.

Furness, R.W., Greenwood, J.J.D., Jarvis, P.J., 1993. Can birds be used to monitor the environment? Birds as Monitors of Environmental Change. Springer Netherlands.

Gil-Tena, A., Saura, S., Brotons, L., 2007. Effects of forest composition and structure on bird species richness in a Mediterranean context: implications for forest ecosystem management. Forest Ecology and Management, 242: 470-476.

Gregory, R.D., van Strien, A., Vorisek, P., Gmelig Meyling, A.W., Noble, D.G., Foppen, R.P.B., Gibbons, D.W., 2005. Developing indicators for European birds. Philosophical Transactions of the Royal Society B, 360: 269-288.

Gregory, R.D., van Strien, A., 2010. Wild bird indicators: using composite population trends of birds as measures of environmental health. Ornithological Science, 9: 322.

Hutto, R.L., Pletschet, S.M., Hendricks, P., 1986. A fixedradius point count method for nonbreeding and breeding season use. The Auk, 103: 593-602.

IUCN, 2015. The IUCN Red List of Threatened Species. Version 2015:4.

IUCN, 2018. The IUCN Red List of Threatened Species. Version 2018:1.

Jansson, N., Coskun, M., 2008. How similar is the saproxylic beetle fauna on old oaks (Quercus spp.) in Turkey and Sweden? Revue d'Ecologie (Terre et Vie) Suppl., 10: 91-99.

Julliard, R., Clavel, J., Devictor, V., Jiguet, F., Couvet, D., 2006. Spatial segregation of specialists and generalists in bird communities. Ecology letters, 9: 1237-1244.

Kaniewski, D., de Laet, V., Paulissen, E., Waelkens, M., 2007. Long-term effects of human impact on mountainous ecosystems, western Taurus Mountains, Turkey. Journal of Biogeography, 34: 1975-1997.

Kavgaci, A., Čarni, A., Tecimen, B., Özalp, G., 2010. Diversity and differentiation of oak forests in NW Thrace (Turkey). Archives of Biological Sciences, 62: 705-718.

Kaya, Z, Raynal, D.J., 2001. Biodiversity and conservation of Turkish forests. Biological Conservation, 97: 131141.
Khanaposhtani, M.G., Kaboli, M., Karami, M., Etemad, V., 2012. Effect of habitat complexity on richness, abundance and distributional pattern of forest birds. Environmental Management, 50: 296-303.

Kiliç, S., 2015. Doğu Anadolu Meşesi (Quercus brantii) ve Mazı Meşesi (Quercus infectoria) yapraklarının silajlarına ilave edilen değişik meyve posalarının silaj kalitesi üzerine etkilerinin belirlenmesi. Doktora Tezi, Dicle Üniversitesi, Fen Bilimleri Enstitüsü, Diyarbakır.

Kılıç, D.T., Eken, G., 2004. Türkiye'nin Önemli Kuş Alanlari. 2004 Güncellemesi. Doğa Derneği, Ankara.

Kirwan, G., Demirci, B., Welch, H., Boyla, K., Özen, M., Castell, P., Marlow, T., 2008. The Birds of Turkey. A\&C Black Publishers Limited, London.

MGM, 2017. Climate of Turkey, Meteoroloji Genel Müdürlüğü, Ankara, http://www.emcc.mgm.gov.tr/files/climateofturkey.pdf, Erișim: 26.10.2018.

Moskát, C., 1991. Multivariate plexus concept in the study of complex ecological data: an application to the analysis of bird-habitat relationships. Coenoses, 6: 7989.

Moskát, C., Waliczky, Z., 1992. Bird-vegetation relationships along ecological gradients: ordination and plexus analysis. Ornis Hungarica, 2: 45-60.

Müller, J., Hothorn, T., 2004. Maximally selected twosample statistics as a new tool for the identification and assessment of habitat factors with an application to breeding-bird communities in oak forests. European Journal of Forest Research, 123: 219-228.

OGM, 2015. Türkiye Orman Varlığı. Orman Genel Müdürlüğü, Ankara.

Özkan, K., Svenning, J-C., Jeppesen, E., 2010. Environmental species sorting dominates forest-bird community assembly across scales. Journal of Animal Ecology, 82: 266-274.

Pereira, P., Godinho, C., Roque, I., Marques, A., Branco, M., Rabaça, J.E., 2014. Time to rethink the management intensity in a Mediterranean oak woodland: the response of insectivorous birds and leaf-chewing defoliators as key groups in the forest ecosystem. Annals of Forest Science, 71: 25-32.

Ranius, T., Niklasson, M., Berg, N., 2009. Development of tree hollows in pedunculate oak (Quercus robur). Forest Ecology and Management, 257: 303-310.

Rey-Benayas, J.M., Galván, I., Carrascal, L.M., 2010. Differential effects of vegetation restoration in Mediterranean abandoned cropland by secondary succession and pine plantations on bird assemblages. Forest Ecology and Management, 260: 87-95.

Robles, H., Ciudad, C., Matthysen, E., 2011. Tree-cavity occurrence, cavity occupation and reproductive performance of secondary cavity-nesting birds in oak forests: The role of traditional management practices. Forest Ecology and Management, 261: 1428-1435.

Roché, J.C., Chevereau, J. ., 2001. Guía sonora de las aves de Europa. 10 CD. Lynx, Barcelona.

Saab, V., 1999. Importance of spatial scale to habitat use by breeding birds in riparian forests: a hierarchial analysis. Ecological Applications, 9: 135-151. 
Sama, G., Jansson, N., Avcı, M., Sarıkaya, O., Coşkun, M., Kayış, T., Özdikmen, H., 2011. Preliminary report on a survey of the saproxylic beetle fauna living on old hollow oaks (Quercus spp.) and oak wood in Turkey (Coleoptera: Cerambycidae). Mun. Ent. Zool., 6(2): 819831.

Svensson, L., Mullarney, K., Zetterström, D., 2009. Fågelguiden - Europas och Medelhavsområdets fåglar i fält. Andra omarbetade och utökade upplagan. Bonnier Fakta.

Telleria, J.L., Santos, T., Sánchez, A., Galarza, A., 1992. Habitat structure predicts bird diversity distribution in Iberian forests better than climate. Bird Study, 39: 6368.

Telleria, J.L., Santos, T., 1994. Factors involved in the distribution of forest birds in the Iberian Peninsula. Bird Study, 41: 161-169.

Touihri, M., Villard, M-A., Charfi-Cheikhrouha, F., 2015. Nesting habitat requirements of two species of North African woodpeckers in native oak forest. Bird Study, 62: 386-393.
Uğurlu, E., Roleček, J., Bergmeier, E., 2012. Oak woodland vegetation of Turkey - a first overview based on multivariate statistics. Applied Vegetation Science, 15: 590-608.

Uslu, E., Bakiş, Y., Babaç, M., 2011. A study on biogeographical distribution of Turkish oak species and their relations with the Anatolian Diagonal. Acta Botanica Hungarica, 53(3-4). DOI: 10.1556/ABot.53.2011.3-4.21: 423-440.

van Dorp, D., Opdam, P.F.M., 1987. Effects of patch size, isolation and regional abundance on forest bird communities. Landscape Ecology, 1: 59-73.

Verner, J., 1985. Assessment of counting techniques. In Johnston, R.F. (Eds.) Current Ornithology. New York, Plenum Press.

Waliczky, Z., 1991. Bird community changes in differentaged oak forest stands in the Buda-hills (Hungary). Ornis Hungarica, 1: 1-9.

Yaltirik, F., 1984. Türkiye Meşeleri. Teşhis Kılavuzu, Orman Fakültesi, İstanbul Üniversitesi. 